\title{
Seroprevalence of zika virus in a cattle flock
}

\author{
Bianca Freire ${ }^{1, *}$ (D) https://orcid.org/0000-0001-5495-174X \\ Fabiola Souza1 (D) https://orcid.org/0000-0003-4981-3603 \\ Vera Cláudia Lorenzetti Magalhães Curci² (D) https://orcid.org/0000-0003-3393-0493 \\ Gustavo Pavan Mateus² (D) https://orcid.org/0000-0001-7620-1026 \\ Adilson Marini² (D) https://orcid.org/0000-0002-9545-902X \\ Solange de Oliveira' ${ }^{1 D}$ https://orcid.org/0000-0003-3209-1878 \\ Adriana Hellmeister de Campos Nogueira Romaldini ${ }^{1}$ (D) https://orcid.org/0000-000 1-5324-1279 \\ Eliana de Stefano' (D) https://orcid.org/0000-0002-7223-0134 \\ Helio Shimozako' (D) https://orcid.org/0000-0003-1941-9330 \\ Liria Hiromi Okuda' (D) https://orcid.org/0000-0001-7865-3659 \\ 1. Instituto Biológico de São Paulo - Laboratório de Viroses de Bovídeos - São Paulo (SP), Brazil. \\ 2. Agência Paulista de Tecnologia dos Agronegócios - São Paulo (SP), Brazil. \\ *Corresponding author: biancacfreire@gmail.com
}

\begin{abstract}
The present research evaluated the seroprevalence of anti-zika virus (anti-ZIKV) antibodies by virus neutralization test (VNT) in 529 bovines from Andradina city, São Paulo state, Brazil. The reading was performed in an inverted optical microscope, considering reagents when the antibodies were capable to neutralize the ZIKV. Of the 529 samples, 53 (10.01\%) were reagents. The animals were healthy at the time of collection. The samples were collected in February 2018, a favorable period for the multiplication of the vector and the highest risk of disease transmission. None of the animals showed anti-bovine viral diarrhea virus (anti-BVDV) antibodies, ruling out a possible cross-reaction, reinforcing the possible contact of the bovine with the ZIKV. In the herd, 88 pregnant females were evaluated; of these, 12 cows were reactive, with no history of reproductive problems or fetal malformations. This is the first research on the seroprevalence of ZIKV in cattle in Brazil, and studies should continue to evaluate cattle as a possible host of this arbovirus and its possible consequences for unique health and agribusiness.
\end{abstract}

Keywords: Zika fever; virus neutralization; serodiagnosis.

\section{INTRODUCTION}

In Brazil, arboviruses such as dengue, chikungunya, and zika fever have become the object of study in several areas: medical, environmental, sanitation, and public health, due to their form of transmission, difficulty in controlling the vector or how to stop this cycle. Assessing the impact caused by these agents is essential for decision-making regarding measures to control these diseases (LIMA-CAMARA, 2016).

Belonging to the family Flaviviridae, genus Flavivirus, the zika virus (ZIKV), the agent responsible for causing zika fever has been widely studied in Brazil after the World Health Organization associated the cases of microcephaly in babies, as well as those related to the Guillain-Barré syndrome (GBS), with this agent (BRAZIL, 2015).

For lack of research, the number of animal species affected by ZIKV is unknown, although it was first identified in 1947 in Rhesus monkeys in Uganda, Africa. Within the family Flaviviridae, in addition to the genus Flavivirus, the genus Pestivirus is included with the bovine viral diarrhea virus (BVDV), which has symptoms in bovine fetuses very similar to that presented by ZIKV in humans, such as malformation, microcephaly, and hydrocephalus. The BVDV transmission is remote, and there is no scientific evidence of interspecies and vector transmission (VOROU, 2016). Cross-reactions hinder the applicability of serological tests. In humans, the most common cross reactions are between dengue virus (DENV) and ZIKV (VOROU, 2016).

Received: Nov 25, 2019. Accepted: Oct 05,2021

Associate Editor: Silvia Galleti

Peer Review History: Double-blind Peer Review. 
The ZIKV is transmitted to humans by the bite of mosquitoes of the genus Aedes, most commonly by species Aedes aegypti and Aedes albopictus (FORATTINI, 1997). The ZIKV has this name because of its discovery in the Zika forests in the province of Entebbe/Uganda, where researchers used sentinel monkey (Macaca mulatta) sentinels for monitoring yellow fever, and accidentally isolated the ZIKV from blood samples from one of these individuals (BRAZIL, 2016; FAUCI; MORENS, 2016). This accidental isolation occurred in 1947, but was only properly identified in 1952 after causing the disease in humans in Uganda and the Republic of Tanzania (FAUCI; MORENS, 2016).

It is estimated that approximately $80 \%$ of humans infected with ZIKV are asymptomatic. When symptoms are present, it is possible to observe headaches, low fever, mild pain in the joints, red spots on the skin, itching, redness, less often swelling, pain in the eyes, sore throat, coughing and vomiting. Generally, the disease occurs in a benign way and the symptoms disappear, however, joint pain can perpetuate for up to four weeks (BRAZIL, 2015). The first documented case of human ZIKV infection was in 1964, when researcher Simpson fell ill and decided to monitor his entire illness, but it was only in November 2015 that the first ZIKV-related death was identified (BRAZIL, 2015).

Associated with ZIKV are GBS and microcephaly. OEHLER et al. (2013) reported the care of a patient, who was admitted to the department of internal medicine at the Hospital Center of French Polynesia, presenting symptoms compatible with GBS, and the clinical signs consisted of paresthesia of the four limbs evolving to ascending muscle weakness with progression on the third day of hospitalization for tetraparesis, diffuse and bilateral myalgia, and asymmetric peripheral facial paralysis. Laboratory tests RT-PCR and ELISA were used to confirm ZIKV infection concomitant with the patient's clinical condition. The serum neutralization test was also carried out to clarify the possible cross-reactivity with dengue virus (DENV), eliminating this possibility. Thus, this became the first documented case in which ZIKV was associated with the development of GBS.

To date, few studies have focused on ascertaining the presence of animals as hosts for ZIKV. Some authors believe that there is no evidence for the participation of nonhuman primates as a reservoir for ZIKV, but we have published reports of the presence of anti-ZIKV in domestic animals such as goats and sheep. (BUENO et al., 2016).

By the indirect hemagglutination test, the presence of anti-ZIKV antibodies was detected in numerous bovine species, among them: Gazella cuvieri (8.3\%), Alcelaphus buselaphus (27.3\%) and Connochaetes taurinus (22.2\%) in Kenya in 1968; Syncerus caffer (88.9\%) and Aepyceros melampus (33.33\%) in Zambia in 1968; Capra aegagrus (0.2\%), Ovis aries (0.7\%) and Bos taurus (0.6\%) in Kenya in 1977; B. taurus (10\%), Bubalus bubalis (8\%) and C. aegagrus (20\%) in Indonesia in 1978; C. aegagrus (2.1\%) and O. aries (2.2\%) in Pakistan in 1983, these being naturally exposed to the agent. In view of these findings, the need to confirm these vertebrates as probable ZIKV reservoirs in nature is highlighted, as well as their importance in the epidemiological chain of this pathogen (BUENO et al., 2016).

Considering that zika fever is an emerging disease in Brazil, which has led to an increase in the number of deaths due to its condition and an increase in cases of microcephaly and neurological manifestations, possibly associated with the occurrence of the disease, the secretariat for surveillance in health (SVS) recommends to the state and municipal secretariats the compulsory notification of all suspected cases (BRAZIL, 2016).

Assessing cattle as a possible host of ZIKV is of paramount importance from an epidemiological point of view due to the measures of control and surveillance of these diseases in public health and economic impact for the animal production chain. Thus, this study evaluated the seroprevalence of ZIKV in a bovine herd, raising questions about its epidemiological importance and its possible impacts on public health and agribusiness.

\section{MATERIAL AND METHODS}

All procedures were performed according to the ethical standards of animal experimentation, adopted by the Brazilian Society of Animal Science by the Brazilian College of Animal Experimentation, and the study was approved by the Animal Experimentation Ethics Committee of the Biological Institute under protocol No. 159/18.

The experiment was carried out with 529 bovine serum samples collected in February 2018 from healthy animals, both sexes, of the Nellore and Aberdeen Angus breeds, of different ages, and not vaccinated against BVD, belonging to the Agency for Agricultural Technology (APTA) - Extreme Western Regional Pole, located in the city of Andradina, São Paulo state. The property is focused on research and heifer auctions. The animals are bred in two kinds of rearing systems: extensive system for Nellore (454 animals). First, the extensive system for Nellore (454 animals), which was divided into batch of Aprisco (366 animals) and pregnant (88 animals). Second, the agrosilvopastoral system for Aberdeen Angus (Angus batch of 75 animals). 


\section{Serum collecting process}

Before blood collecting, the animals were physically restrained, identified and clinically evaluated. Following, they had the external jugular vein was punctured with a Vacutainer needle for blood collection. Four milliliters of blood were collected and the respective serum was released into a dry tube with separating gel. All material used for collection process was properly discarded after its use. Finally, the collected blood sample was kept under refrigeration.

The collected material was properly packed in styrofoam boxes, kept at a temperature of $4{ }^{\circ} \mathrm{C}$ and sent to the laboratory of bovid viruses, at the Instituto Biológico de São Paulo, where it was identified and frozen at $-20^{\circ} \mathrm{C}$.

\section{The virus neutralization test (VNT)}

The present study was performed to analyze the antibodies against ZIKV and possible cross-reaction with BVDV. The VNT was standardized by the Bovid Viruses Laboratory, at the Instituto Biológico, APTA of Secretariat of Agriculture and Supply of the state of São Paulo.

Regarding to VNT test for ZIKV, the first step was the inactivation of complement at $56{ }^{\circ} \mathrm{C}$ for $30 \mathrm{~min}$. Following, a quadruplicate serum sample screening test was performed (22 sera for each plate). One column was reserved for cell control. Then, $70 \mu \mathrm{L}$ of ZIKV at a concentration of 100 tissue culture infectious dose $\left(\mathrm{TCID}_{50 / 70 \mathrm{LL})}\right.$ was added to the corresponding wells. The cut-off point for considering an animal as reactive was 10 . The plates were kept for $1 \mathrm{~h} \mathrm{in} \mathrm{a} \mathrm{CO}_{2}$ incubator at $37^{\circ} \mathrm{C}$ with $5 \% \mathrm{CO}_{2}$. Then, $70 \mu \mathrm{L}$ of Vero cell suspension was added to all cavities, at a concentration of $10^{5} \mathrm{cells} \cdot \mathrm{mL}^{-1}$. It was also included viral retitration and dose plates for each reaction, for validation of the test. The plates were kept under the same controlled conditions of temperature and humidity for up to 5 days. Finally, such plates were read in an inverted optical microscope.

Serum samples considered reactive in the screening test were evaluated to viral titration, starting from the dilution $\log _{10} 0.7$ to $\log _{10} 4$. After adding $70 \mu \mathrm{L}$ of ZIKV at the concentration of $100 \mathrm{TCID}_{50 / 70 \mathrm{~L}}$ in the corresponding wells, the antibody titer ranged from 10 to 5,120 . The plates were kept for $1 \mathrm{~h}$ in a $\mathrm{CO}_{2}$ incubator at a temperature of $37^{\circ} \mathrm{C}$ with $5 \% \mathrm{CO}_{2}$. Then, $70 \mu \mathrm{L}$ of the Vero cell suspension was added, at a concentration of $105 \mathrm{cells} \cdot \mathrm{mL}^{-1}$. The plates were kept under the same controlled conditions of temperature and humidity for up to five days. Finally, those plates were read in an inverted optical microscope. Re-titration and viral dose plates were also included, as well as cytotoxicity and cell controls on each plate.

Regarding BVDV was considered the protocol recommended by the World Organization for Animal Health (OIE, 2015).

\section{RESULTS}

In the present study, the frequency of ZIKV in Nellore cattles (Aprisco and pregnant batches) was 44 animals (8.32\%), with 12 from pregnant and 32 from Aprisco batches. In Aberdeen Angus cattle, it was 9 animals (1.70\%). The 12 pregnant reactive cows had no history of reproductive disorders or fetal malformations. The animals were considered reactive when their antibody titer was greater than 10 .

Considering the approach by breeding system, there were 454 animals in the extensive breeding system and 75 animals in agrosilvopastoral one. As result, 44 animals (9.69\%) were reactive for anti-ZIKV antibodies in the first system and 9 animals (12\%) were reactive in the second one. A higher frequency of reactive animals was observed when kept in an agrosilvopastoral system (as shown in Fig. 1).
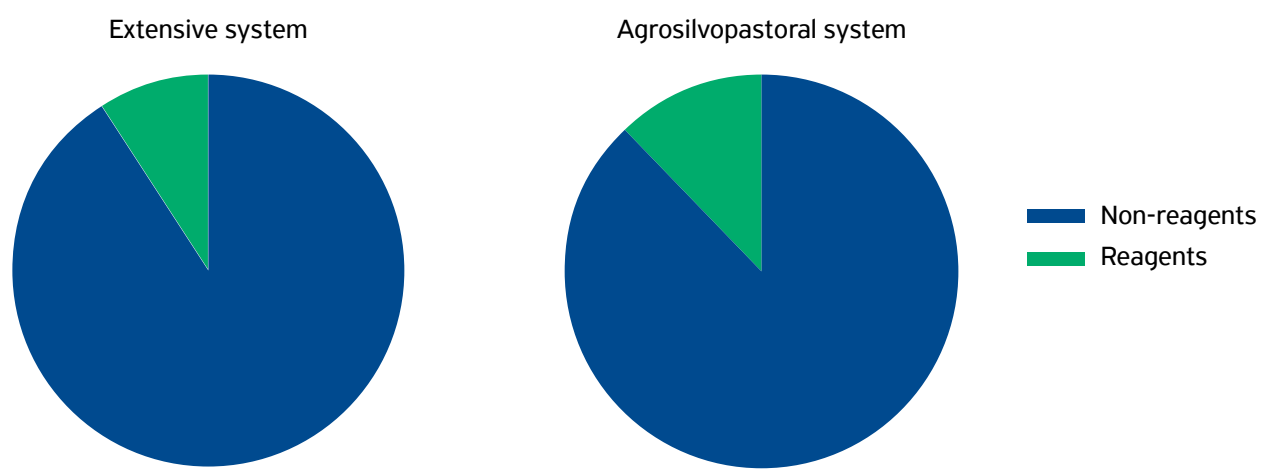

Figure 1. Prevalence of reagent animals sorted by breed and rearing systems. 
All 529 samples tested by VNT technique to search for anti-BVDV antibodies were nonreactive, that is, the possibility of these animals having come into contact with any of the BVDV strains (Type 1,2 and Hobi-like) was ruled out. In this way, it reinforces the contact of these individuals with the ZIKV.

\section{DISCUSSION}

According to a survey by the IBGE (2017), Brazil is one of the largest exporters of beef in the world, reaching the level of the largest producer in 2016, with 209 million heads of cattle (38.6 kg of meat/inhabitant). Recent data show a drop in production of $0.7 \%$ in 2018 when compared to 2017; however, it maintained the position of the largest commercial herd in the world. It is estimated that the country has 213.5 million animals (SARAIVA, 2020).

This is the first study of the seroprevalence of ZIKV in cattle herd in the state of São Paulo. To do so, comprehension about the interaction between cattle and ZIKV raises health issues regarding breeding, management, exposure of agribusiness professionals, risk of dissemination to the population and exportation of live cattle or their byproducts.

Of the 529 animals studied, 53 (10.01\%) were reactive to ZIKV by VNT, while no sample was reactive to the BVDV virus. Of the animals reactive for ZIKV, 32 (6.04\%) animals belonged to the Aprisco batch, 12 (2.27\%) belonged to the pregnant batch and $9(1.70 \%)$ to the Aberdeen Angus batch.

When evaluated by their rearing systems, in the agrosilvopastoral system, the incidence was $12 \%$ (9 animals out of 75), while in the extensive system it was $9.69 \%$ (44 animals out of 454 ).

Some characteristics may have influenced the higher prevalence of reactive animals in the agrosilvopastoral breeding system, as described in Table 1.

Table 1. Characteristics of agrosilvopastoral and extensive breeding systems.

\begin{tabular}{|c|c|c|}
\hline & Agrosilvopastoral system & Extensive system \\
\hline Features & $\begin{array}{l}\text { It integrates agriculture with the preserved area } \\
\text { and livestock; } \\
\text { Pasture taking advantage of agriculture, livestock } \\
\text { and environmental conservation. }\end{array}$ & $\begin{array}{l}\text { Free-bred animals, exclusively on pasture, common } \\
\text { on large farms; } \\
\text { Deforestation and planting of exclusive cattle } \\
\text { pastures is commonly carried out. }\end{array}$ \\
\hline Advantages & $\begin{array}{l}\text { Free-bred animals, exclusively on pasture, common } \\
\text { on large farms; } \\
\text { Deforestation and planting of exclusive cattle } \\
\text { pastures are commonly carried out. }\end{array}$ & $\begin{array}{l}\text { Cheaper (low financial risk); } \\
\text { Natural weaning; } \\
\text { Animals with behavior closer to the natural. }\end{array}$ \\
\hline Disadvantages & $\begin{array}{l}\text { More expensive maintenance; } \\
\text { It needs a greater technical aptitude for } \\
\text { maintenance. }\end{array}$ & $\begin{array}{l}\text { Hit the soil more; } \\
\text { Greater damage to the environment; } \\
\text { Destruction of biodiversity; } \\
\text { Poorly divided pastures and poorly accompanied } \\
\text { animals. }\end{array}$ \\
\hline
\end{tabular}

Source: Data collected from EMBRAPA (2011).

As described in the previous table, the agrosilvopastoral system respects agriculture, livestock and the environment, maintaining a minimum of $20 \%$ of preserved forest, varying according to the lot size and has a higher humidity when compared to the extensive system (EMBRAPA, 2011).

Based on the Köppen classification, the climate of São Paulo is humid subtropical, that is, a dry winter and a commonly rainy summer (MELLO et al., 2017) as well as a higher humidity and temperature allows the reproduction of Aedes spp. mosquitoes (SOUZA et al., 2008). Hypothetically, characteristics of the agrosilvopastoral breeding system may have been responsible for greater animal/vector contact and, consequently, greater seroprevalence in this breeding system.

The study is not enough to affirm that bovine is a possible reservoir of ZIKV, however, it was found that the animals had contact with the virus that causes zika fever and were able to develop an effective immune response against it. The study was also unable to state whether and how these animals respond to a possible viremia, since all of them were healthy and positive females in the reproductive phase did not have a history of abortion or fetal malformations.

The detection of anti-ZIKV antibodies in cattle raises several questions, since there is no satisfactory evidence that this virus sickens non-primate animals. Because of this, it highlights the importance of developing new research in controlled 
environments and in knowingly no-reactive animals with serological and molecular tests, considering before, during and after the exposure of the agent. In this way, it will be able to reliably analyze the probabilities of a greater spread of this disease, as well as its possible impacts on the export of live cattle.

In the light of one health and the emergence of new epizootics, the relevance of this work is given by the evaluation of potential hosts for the zika virus, such as cattle, and possible restriction on international trade.

\section{AUTHORS' CONTRIBUTIONS}

Data curation: Freire, B.; Investigation: Souza, F.; Curci, V.C.L.M.; Marini, A.; Oliveira, S.; Methodology: Romaldini, A.H.C.N.; Stefano, E.; Project administration: Okuda, L.H.; Supervision: Mateus, G. P.; Validation: Shimozako, H.

\section{AVAILABILITY OF DATA AND MATERIAL}

All data generated or analyzed during this study are included in this published article.

\section{FUNDING}

Conselho Nacional de Desenvolvimento Científico e Tecnológico

https://doi.org/10.13039/501100003593

Grant No. 440527/2016-3

Coordenação de Aperfeiçoamento de Pessoal de Nível Superior

https://doi.org/10.13039/501100002322

Grant No. 88881.130751/2016-01

\section{CONFLICTS OF INTEREST}

Not applicable.

\section{ETHICAL APPROVAL}

The study was approved by the Comitê de Ética em Experimentação Animal do Instituto Biológico (CETEA-IB) under protocol No. $159 / 18$.

\section{ACKNOWLEDGEMENTS}

To the Laboratório de Viroses de Bovídeos of the Instituto Biológico de São Paulo; to the Polo Regional Extremo Oeste of the Agência Paulista de Tecnologia Agropecuária (APTA); and to the Instituto de Medicina Tropical for providing the viral strain.

\section{REFERENCES}

BRAZIL. Ministério da Saúde; Secretaria de Vigilância em Saúde; Departamento de Vigilância das Doenças Transmissíveis. Protocolo de vigilância e resposta à ocorrência de microcefalia relacionada à infecção pelo vírus Zika. Brasília: Ministério da Saúde, 2015. Available from: https://portalarquivos2.saude.gov.br/images/pdf/2015/dezembro/09/Microcefalia---Protocolo-de-vigil--ncia-e-resposta---vers-o-1----09dez2015-8h.pdf. Access on: 5 Oct. 2019.

BRAZIL. Ministério da Saúde; Secretaria de Vigilância em Saúde; Departamento de Vigilância das Doenças Transmissíveis. Dengue: diagnóstico e manejo clínico: adulto e criança. 5th. Ed. Brasília: Ministério da Saúde, 2016. Available from: https://portalarquivos2.saude. gov.br/images/pdf/2016/janeiro/14/dengue-manejo-adulto-crianca-5d.pdf. Access on: 3 Oct. 2016.

BUENO, M.G.; MARTINEZ, N.; ABDALLA, L.; SANTOS, C.N.D.; CHAME, M. Animals in the Zika Virus Life Cycle: What to Expect from Megadiverse Latin American Countries. PLoS Neglected Tropical Diseases, San Francisco, v.10, n.12, p.e0005073, 2016. https://doi. org/10.1371/journal.pntd.0005073

EMBRAPA - Empresa Brasileira de Pesquisa Agropecuária. Integração Lavoura-Pecuária-Floresta: O que é ILPF? Brasília, DF: EMBRAPA, 2011. Available from: https://www.embrapa.br/tema-integracao-lavoura-pecuaria-floresta-ilpf/nota-tecnica. Access on: 2 Nov. 2019.

FAUCI, A.S.; MORENS, D.M. Zika Virus in the Americas - Yet Another Arbovirus Threat. The New England Journal of Medicine, Massachusetts, v.374, n.7, p.601-604, 2016. https://doi.org/10.1056/NEJMp16002971 
FORATTINI, O.P.; KAKITANI, I.; SALLUM, M.A.M.; REZENDE, L. Produtividade de criadouro de Aedes albopictus em ambiente urbano. Revista de Saúde Pública, São Paulo, v.31, n.6, p.545-555, 1997. https://doi.org/10.1590/S0034-89101997000700002

IBGE - Instituto Brasileiro de Geografia e Estatística. Rebanho de bovinos tem maior expansão da série histórica. Rio de Janeiro: IBGE, 2017. Available from: https://agenciadenoticias.ibge.gov.br/agencia-noticias/2012-agencia-de-noticias/noticias/16994-rebanho-debovinos-tem-maior-expansao-da-serie-historica. Access on: 11 Nov. 2019

LIMA-CAMARA, T.N. Emerging arboviruses and public health challenges in Brazil. Revista de Saúde Pública, São Paulo, v.50, p.36, 2016. https://doi.org/10.1590/S1518-8787.2016050006791

MELLO, Y.R.; LOPES, F.C.A.; ROSEGHINI, W.F.F. Características climáticas e análise rítmica aplicada a episódios extremos de precipitação e temperatura no município de Paranaguá, PR, Revista Brasileira de Climatologia, Curitiba, v.20, p.313-336, 2017. https://doi.org/10.5380/ abclima.v20i0.48594

OEHLER, E.; WATRIN, L.; LARRE, P.; LEPARC-GOFFART, I.; LASTÈRE, S.; VALOUR, F.; BAUDOUIN, L.; MALLET, H.P.; MUSSO, D.; GHAWCHE, F. Zika virus infection complicated by Guillain-Barré syndrome - Case report, French Polynesia, December 2013. Eurosurveillance, Paris, v.19, n.9, p.20720, 2013. https://doi.org/10.2807/1560-7917.ES2014.19.9.20720

OIE - Word Organization for Animal Health. Bovine viral diarrhoea. In: Manual of Diagnostic Tests and Vaccines for Terrestrial Animals. Paris: OIE, 2015. 1075p. Chapter 3.4.7. Available from: https://www.oie.int/fileadmin/Home/eng/Health_standards/tahm/3.04.07_BVD. pdf. Access on: 10 Nov. 2019.

SARAIVA, A. Rebanho bovino reduz em 2018, em ano de crescimento do abate e exportação. Agência IBGE Notícias: Estatísticas Econômicas, 2020. Available from: https://agenciadenoticias.ibge.gov.br/agencia-noticias/2012-agencia-de-noticias/noticias/25483-rebanho-bovinoreduz-em-2018-em-ano-de-crescimento-do-abate-e-exportacao. Access on: 11 Nov. 2019.

SOUZA, R.C.; CHIVA, E.Q.; LAMBERTI, M.P. Relação entre as condições ambientais e o número de focos de mosquitos Aedes aegypti e Aedes albopictus no município de Uruguaiana, RS. Biodiversidade Pampeana, Uruguaiana, v.6, n.2, p.44-48, 2008. Available from: https:// revistaseletronicas.pucrs.br/index.php/biodiversidadepampeana/article/view/4888. Access on: 11 Nov. 2019.

VOROU, R. Zika virus, vectors, reservoirs, amplifying hosts, and their potential to spread worldwide: what we know and what we should investigate urgently. International Journal of Infectious Diseases, Aarhus, v.48, p.85-90, 2016. https://doi.org/10.1016/j.ijid.2016.05.014 